\title{
Kernos
}

Revue internationale et pluridisciplinaire de religion grecque antique

$31 \mid 2018$

Varia

\section{A Dedication of a Naos to Skorpon's Ourania in Ascalon (Ashkelon) - Illustrations}

Avner Ecker, Hannah M. Cotton, Saar Ganor and David J. Wasserstein

\section{OpenEdition}

\section{Journals}

Electronic version

URL: http://journals.openedition.org/kernos/3049

DOI: 10.4000/kernos.3049

ISSN: 2034-7871

\section{Publisher}

Centre international d'étude de la religion grecque antique

Printed version

Date of publication: 1 December 2018

ISBN: 978-2-87562-055-2

ISSN: 0776-3824

Electronic reference

Avner Ecker, Hannah M. Cotton, Saar Ganor and David J. Wasserstein, "A Dedication of a Naos to Skorpon's Ourania in Ascalon (Ashkelon) - Illustrations", Kernos [Online], 31 | 2018, Online since 01 October 2018, connection on 24 January 2021. URL: http://journals.openedition.org/kernos/3049 ; DOI: https://doi.org/10.4000/kernos.3049

This text was automatically generated on 24 January 2021 .

Kernos 


\section{A Dedication of a Naos to Skorpon's Ourania in Ascalon (Ashkelon) - Illustrations}

Avner Ecker, Hannah M. Cotton, Saar Ganor and David J. Wasserstein

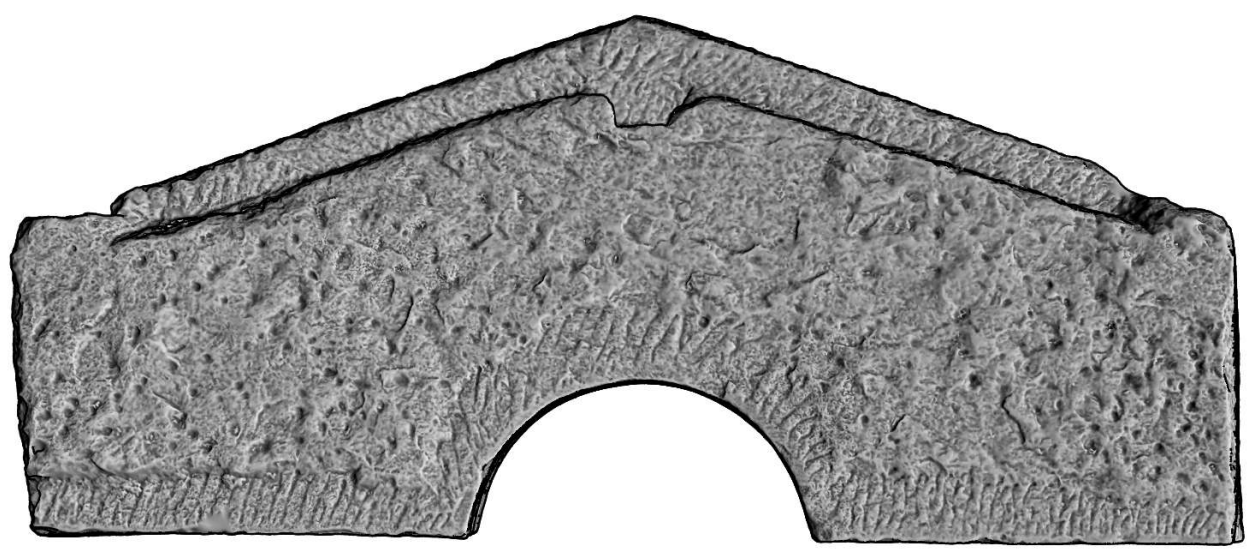

INSCRIPTION OF ASHKELON (BACK OF THE gABLE) 


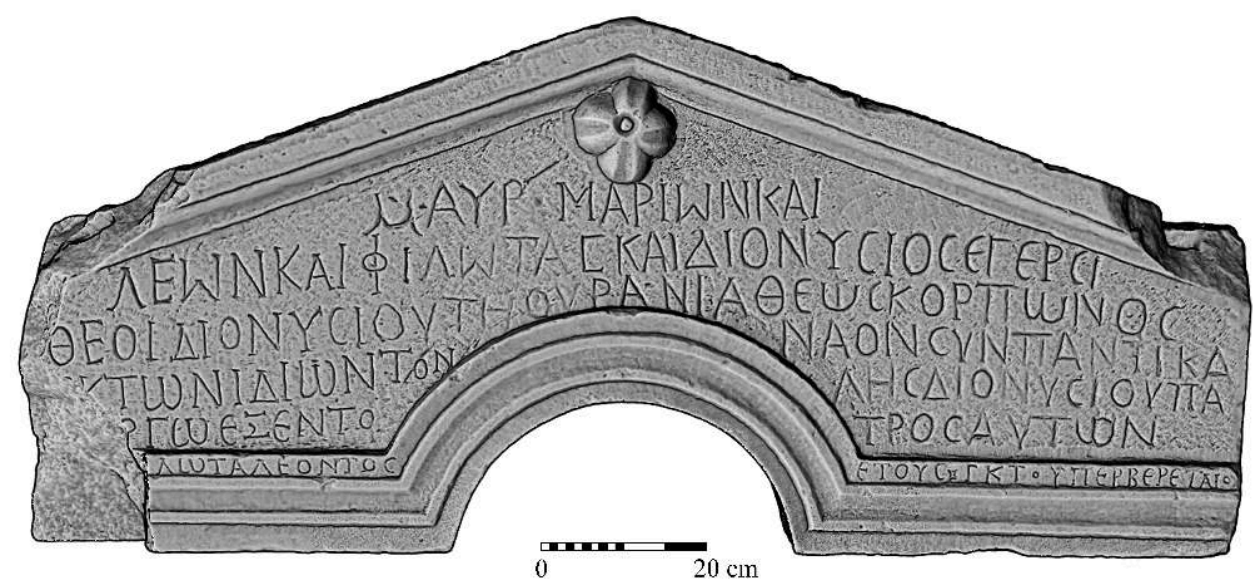

INSCRIPTION OF ASHKELON (INSCRIBED gABLE)

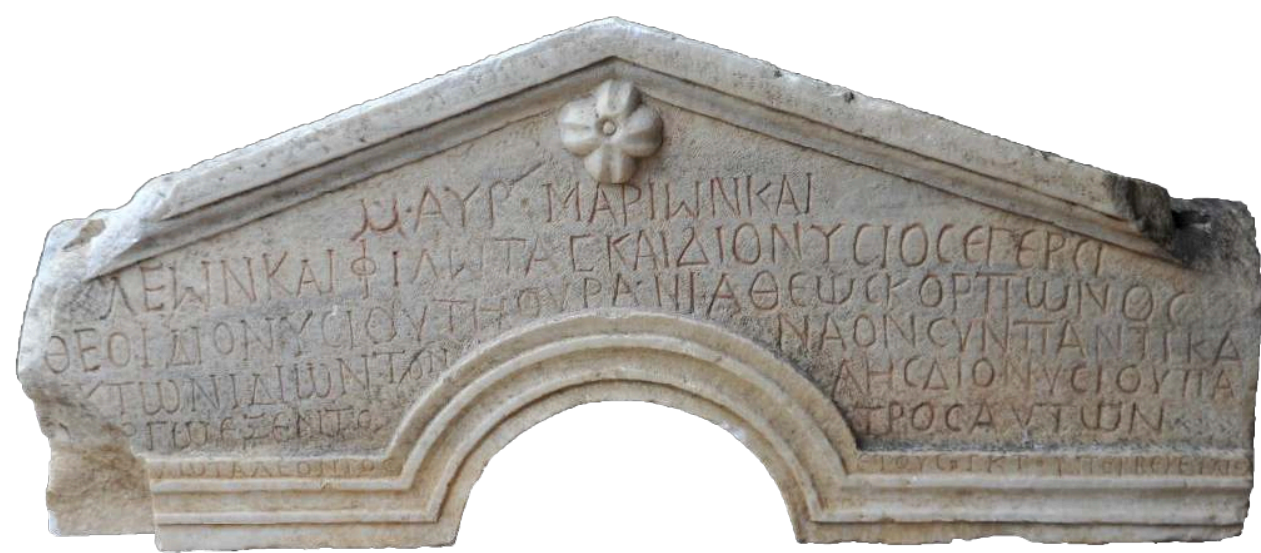

INSCRIPTION OF ASHKELON (INSCRIBED gABLE) 


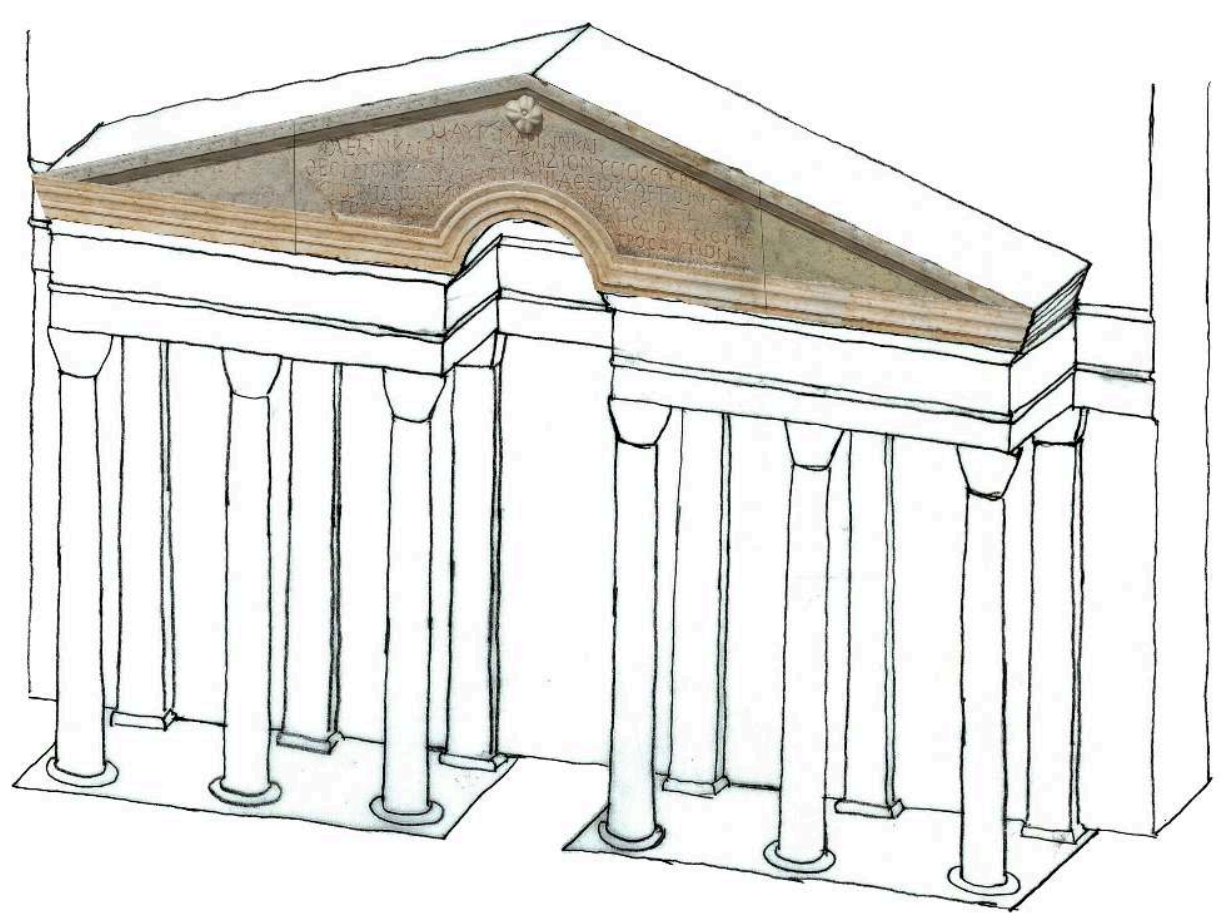

INSCRIPTION OF ASHKELON (RECONSTRUCTION)

\section{ABSTRACTS}

An inscribed marble gable found near the ancient city center of Ascalon (modern Ashkelon) is published. The inscription (of AD 220) records the erection and dedication of a temple in honor of the goddess "Ourania of Skorpon". Ourania Aphrodite was a resident deity in Ascalon and this appears to be the first tangible piece of evidence confirming the ancient ties linking her to the city. The word egersitheos, revivifier of a deity, in this inscription is otherwise unattested.

Publication d'un fronton en marbre trouvé près du centre de l'ancienne ville d'Ascalon (aujourd'hui Ashkelon). L'inscription (datée de 220 ap. J.-C.) évoque la construction et la dédicace d'un temple en l'honneur de la déesse "Ourania de Skorpon". Aphrodite Ourania était une divinité locale à Ascalon, et ce fragment semble bien être la première attestation matérielle confirmant les liens anciens entre la déesse et la ville. Le mot egersitheos, «celui qui revivifie une divinité », n'est pas attesté ailleurs.

\section{AUTHORS}

\section{AVNER ECKER}

The Martin (Szusz) Department of Land of Israel Studies and Archaeology, Bar-Ilan University avner.ecker@biu.ac.il 
HANNAH M. COTTON

Department of Classics, The Hebrew University of Jerusalem, Jerusalem 91905 hannah.cotton@mail.huji.ac.il

SAAR GANOR

Ascalon District Archaeologist, Israel Antiquities Authority, P.O. Box 271, Omer 84965, Israel saarg@israntique.org.il

\section{DAVID J. WASSERSTEIN}

Vanderbilt University, Department of History, PMB 351802, 2301 Vanderbilt Place, Nashville, TN 37235-1802, USA

david.wasserstein@Vanderbilt.Edu 